Archives of Agriculture and Environmental Science

\title{
A review on production status and growing environments of rice in Nepal and in the world
}

\author{
Nirmal Gadal $1^{{ }^{*}}$ (D) , Jiban Shrestha ${ }^{2}$, Mina Nath Poudel ${ }^{3}$ and Bhanu Pokharel ${ }^{4}$ \\ ${ }^{1}$ Food Security and Agriculture Business Promotion Division, Ministry of Land Management, Agriculture and Cooperatives, \\ Provice-3, NEPAL \\ ${ }^{2}$ Nepal Agricultural Research Council, Agriculture Botany Division, Khumaltar, Lalitpur, NEPAL \\ ${ }^{3}$ National Agriculture Genetic Resource Centre, NARC, Khumaltar, NEPAL \\ ${ }^{4}$ Regional Agricultural Research Station, NARC, Doti, NEPAL \\ *Corresponding author's E-mail: nirmal.gadal2006@gmail.com
}

\section{ARTICLE HISTORY}

Received: 19 January 2019

Revised received: 02 February 2019

Accepted: 14 February 2019

\begin{abstract}
Rice is a major food crop for the people of the world. The role of rice is inevitable in the current and future global food security. It is the number one staple food crop in Nepal and contributes significantly to livelihood of majority of people and to the national economy. This article reviews global rice production scenarios; figures out global Mega Rice Environments (MREs) and based on these analyses, the authors developed Nepal's Rice Production Environments (RPEs). The Asian countries dominate the global rice production. India has the largest area of rice cultivation. China is the world's largest producer of rice. Rice productivity is highest in Japan. Rice is cultivated in diverse agro-ecosystems. Rice environments are classified mainly based on land types (upland vs. lowland) and water regimes (irrigated and rainfed). The MREs of the world are classified into seven categories (Four irrigated, two rainfed and one for deep water rice). A total of nine RPEs were identified for Nepal- six under irrigated and three under rainfed conditions. The findings of this study are useful for rice researchers, producers and policy makers.
\end{abstract}

(C)2019 Agriculture and Environmental Science Academy

Citation of this article: Gadal, N., Shrestha, J., Poudel, M.N. and Pokharel, B. (2019). A review on production status and growing environments of rice in Nepal and in the world. Archives of Agriculture and Environmental Science, 4 (1): 83-87, https://dx.doi.org/10.26832/24566632.2019.0401013

\section{INTRODUCTION}

Rice is one of the most important staple foods for more 3.5 billion people in the world (CGIAR, 2016). Seventeen countries in Asia and the Pacific, nine countries in North and South America and eight countries in Africa mostly depend on rice for staple food (ibid). Rice provides 20 percent of the world's dietary energy supply, while wheat and maize supplies 19 and 5 percent respectively (Alexandratos and Jelle, 2012). From this perspective, rice is the most important strategic crop for food and nutrition security globally. Two species of rice- Oryza sativa (Asian rice) and Oryza glaberrima (African rice) are known of their commercial value. However, Oryza glaberrima is cultivated in the very limited areas of South Africa. Oryza sativa the most important commercial species of rice is differentiated into three sub species- indica, japonica and javanica based on their commer- cial production zones. The sub-species- indica refers to the tropical and sub-tropical varieties grown throughout South and in South-East Asia and Southern China. The variety japonica is grown in temperate areas of Japan, China, Nepal and Korea, while javanica varieties are grown in Indonesia.

It is reported that rice in Nepal (and in India and Southeast Asia) was introduced from mainland China during the late $3^{\text {rd }}$ millennium BC (ricepedia.org). However, commercial production of rice in Nepal is believed to be started some five hundred years ago (Mallick, 1982; Agrama et al., 2010). Although Nepal contribute very little in global rice production and trade, but it plays significant role in the national economies. Rice dominates the country's crop sector accounting for over 42.5 percent (168,047 ha) of the total area under food grains and shares 51.6 percent in total food grain production (MOAD, 2017). As the most important staple food of Nepalese people, rice supplies 
about $40 \%$ of the food calorie intake and contributes nearly $20 \%$ to the agricultural gross domestic product (AGDP) and almost $7 \%$ to GDP (DoA/CDD, 2015). Rice only accounts for more than $50 \%$ of the total calories of Nepalese people (Kharel et al., 2018).

\section{Global rice production and Rice Mega Environments (RMEs)}

The Asian countries dominate the global rice production (Table 1). China tops the list of top 10 rice producing nations with a production of 145,500 million tons. The production record puts India in the second position as the country produces 103,500 million tons. The list, which is dominated by the Asian countries, puts Brazil on the $9^{\text {th }}$ position 8,000 million tons and Japan on the $10^{\text {th }}$ position with 7,900 million tons. Indonesia, Bangladesh and Vietnam have found place among the top five rice producing countries. According to USDA projection global rice area, yield and production will increase by $3.8,7.2$ and 11.3 respectively by 2025/26 (base year 2015/16). Although India has the largest rice areas in the world, yield is quite low ( $2.4 \mathrm{t} / \mathrm{ha})$. The highest rice yield in the in the world during $2015 / 16$ was achieved by Japan (4.91 t/ha) and followed by China ( $4.79 \mathrm{t} / \mathrm{ha}$ ).

It is expected that the demand for rice in the coming years will grow to at least 2035 (FAO, 2017). It is expected that in the world the demand for milled rice will increase to 496 million tons in 2020 to 439 million tons in 2010. By 2035, this requirement will increase to around 555 million tons. According to this report, especially in Africa and low-income Asian countries (Afghanistan, North Korea, Nepal and Vietnam), it will continue to grow in the future of rice consumption growth. However, per capita rice consumption has started to decline in the middle and high-income Asian countries like Japan, Taiwan and the Republic of Korea with growing prosperity as income grows, per capita rice consumption is decline as consumers substitute rice with high-cost quality food containing more protein and vitamins such as processed rice, vegetables, bread, fish and meat (Alias et al., 2005). In sub-Saharan Africa, rice is considered the fastestgrowing staple food with the annual per capita rice consumption nearly doubling since the 1970 s and onwards. In the Caribbean and Latin America, rice consumption has increased by $40 \%$ in the last two decades. Other areas showing a significant increase in rice consumption are- the Middle East, in the United States and the members of the European Union (ibidem).

Information on rice producing and consuming countries confirms that rice is grown in a variety of environments ranging from tropical to temperate and in different water regimes and topographic conditions. Rice is produced from the most humid regions of the world to the driest deserts. It occurs at the Arakan coast in Myanmar, where the growing season has an average rainfall of more than $5100 \mathrm{~mm}$ and in Al Hasa Oasis, Saudi Arabia, where annual rainfall is below $100 \mathrm{~mm}$. Temperatures are very different. In the Upper Sind in Pakistan, rice season is $33^{\circ} \mathrm{C}$; In Otaru, Japan, the average temperature of the growing season is $17^{\circ} \mathrm{C}$. Crops are grown at sea level at sea level and in delta regions of Asia, up to 3,050 m on the slopes of Nepal. Rice is also grown in a very wide range of solar radiation up to a potential of $95 \%$ in southern Egypt and Sudan, from a
$25 \%$ potential in the main rice season in Myanmar, Thailand and Indian Assam regions (GRiSP, 2013). ).

Until 1980s, there was a huge confusion and uncertainties in portraying precise terminologies to describe various rice environments (Swaminathan, 1984; Serraj et al., 2011). Classification was important especially for international and national rice breeding programs for identifying, exchange and develop rice varieties in a scientific and strategic way. Based on this need, IRRI International Rice Research Conference held in 1982 decided to establish a widely representative International Committee to develop classification system for rice growing environments at global level (Swaminathan, 1984; Peng et al., 2008; Yuan, 2017). The committee in 1984 proposed rice environments into five major categories and each category were divided into distinct subcategories. Factors such as water regime (deficit, excess, or optimum), drainage (poor or good), temperature (optimum or low), soils (normal or problem), and topography (flat or undulating) were considered in naming the global rice production environments.

More recent classification by Dawe et al. (2010) somehow departs from the former classification by Khush (1984; Singh et al., 2002). According to this global rice production environments are classified into seven categories (Four irrigated, two rainfed and one for deep water rice). The feature of this classification is the integration of the overall cropping systems with other criteria (Table 3).

\section{Rice Production Environments (RPEs) in Nepal}

In Nepal, rice is grown in three agro-ecological regions (Terai and Inner Terai- 67 to 900; Mid Hills- 1000 to 1500 masl; and High Hills- 1500 to 3050 masl) under two water regimes (Irrigated, Un-irrigated) and in two topographic conditions (lowland and upland). In general, Terai represent tropical climate where as mid hills and high hills correspond to sub tropical and warm temperate climates respectively. These variations have made classification of rice growing environment in Nepal a complex task. By combining these factors and considering the Global Mega Rice Environments (MREs) criteria, Table 4 summarizes major rice growing environments in Nepal. It can be noted that water regimes, agro-ecological types and topography are the major factors explaining the variability among rice production domains in the country.

The Terai region, considered the granary of the country, accounts for about 70 percent of the country's rice output; the hills produce 27 percent, and the mountain about 3 percent. Available data shows that only about $7 \%$ of the rice areas have assured irrigation during summer, winter and spring seasons allowing farmers to produce double rice crop in a years. Although in a very limited areas, farmers in the eastern Terai produce three rice crops in a year. In the mid hills and valleys (warm sub tropical climate) with year round assured irrigation facilities rice farmer grow spring rice in addition to main season rice. However, majority of the rice in the mid hills are produced as a single crop in the pond terraces. In the high hills up to 3,000 $\mathrm{m}$ irrigated rice is grown only once in a year due to longer growing period. 
In rainfed areas (in all the three ecologies) rice is transplanted with the onset of the monsoon rain between June and August and harvested from September to November. The monsoon rain first arrives in the eastern part of the country and gradually advances to the west. Majority of the rice areas in the terai and inner terai are rainfed. In the upland areas of the terai and the hills upland rice variety (Ghaiya) are grown. Due to extreme lower yield of local
Ghaiya varieties farmers are gradually Ghaiya rice with the maize. In recent years, with the scientific innovations, farmers in the terai upland environment are producing hybrid rice (e.g. US 312) as intercrop with maize. This kind of cropping system is traditional for far west region where farmers mix Ghaiya and maize. However, farmers in the central terai are gradually being attracted with hybrid rice and maize intercropping due to higher yield and returns.

Table 1. Area, production and yield of top 10 rice producing countries in the world, 2015/16 (USDA, 2016).

\begin{tabular}{|c|c|c|c|c|c|c|c|}
\hline S.N. & Country & Area (1000 ha) & Yield (t/ha) & Production (1000 tons) & Area rank & Yield rank & Production rank \\
\hline 1 & China & 30350 & 4.79 & 14550 & II & II & $\mathrm{I}$ \\
\hline 2 & India & 43200 & 2.40 & 10350 & i & & II \\
\hline 3 & Indonesia & 12160 & 2.99 & 3630 & III & & III \\
\hline 4 & Bangladesh & 12000 & 2.88 & 3460 & & & \\
\hline 5 & Vietnam & 7660 & 3.68 & 2820 & & III & \\
\hline 6 & Thailand & 9650 & 1.70 & 1640 & & & \\
\hline 7 & Myanmar & 6800 & 1.79 & 1220 & & & \\
\hline 8 & Philippines & 4500 & 2.56 & 1150 & & & \\
\hline 9 & Brazil & 2300 & 3.48 & 800 & & & \\
\hline \multirow[t]{2}{*}{10} & Japan & 1610 & 4.91 & 7900 & & I & \\
\hline & World & 159167 & 2.97 & 47349.8 & & & \\
\hline
\end{tabular}

Table 2. Rice production environments in the world (Khus et al., 1984).

\begin{tabular}{ll}
\hline Main Categories & Sub-categories \\
\hline 1. Irrigated & Irrigated with favorable temperature \\
& Irrigated, low-temperature, tropical zone \\
& Irrigated, low-temperature, temperate zone \\
2. Rainfed Lowland & Rainfed shallow, favorable \\
& Rainfed shallow, drought-prone \\
& Rainfed shallow, drought-and submergence-prone \\
& Rainfed shallow, submergence-prone \\
& Rainfed medium deep, waterlogged \\
& Deep water \\
& Very deep water \\
3. Deep water & Favorable upland with long growing season (LF) \\
& Favorable upland with short growing season (SF) \\
4. Upland & Unfavorable upland with long growing season (LU) \\
& Unfavorable upland with short growing season (SU) \\
& Tidal wetlands with perennially fresh water \\
5. Tidal wetlands & Tidal wetlands with seasonally or perennially saline water 'Tidal wetlands with acid sulfate soils Tidal wetlands \\
& with peat soils \\
\hline
\end{tabular}

Table 3. Rice mega-environments (RMEs), relative areas and major producing regions.

\begin{tabular}{|c|c|c|c|c|}
\hline \multirow{2}{*}{ RMEs } & \multicolumn{2}{|r|}{ Description } & \multirow{2}{*}{ Major regions } & \multirow{2}{*}{$\begin{array}{l}\text { Percentage of area (160 } \\
{ }^{*} \text { Mha)- average of } 2008-10\end{array}$} \\
\hline & Hydro-morphology & Climate & & \\
\hline 1 & Irrigated & $\begin{array}{l}\text { Warm to hot-tropics (rice all } \\
\text { seasons) and subtropics (double } \\
\text { crop summer rice) }\end{array}$ & $\begin{array}{l}\text { Indonesia, Sri Lanka, Vietnam, the } \\
\text { Philippines, south-eastern India, south- } \\
\text { ern China, Bangladesh }\end{array}$ & 25 \\
\hline 2 & Irrigated & $\begin{array}{l}\text { Warm-tropics (higher altitudes) } \\
\text { and subtropics (sole rice after } \\
\text { winter crop) }\end{array}$ & $\begin{array}{l}\text { South Asia hills, Indo-Gangetic Plain, } \\
\text { central China }\end{array}$ & 16 \\
\hline 3 & Irrigated & $\begin{array}{l}\text { Temperate (summer rice after } \\
\text { winter fallow, warm and humid) }\end{array}$ & $\begin{array}{l}\text { Japan, Korean peninsula, north-eastern } \\
\text { China, southern Brazil, southern USA }\end{array}$ & 15 \\
\hline 4 & Irrigated & $\begin{array}{l}\text { Temperate (summer rice after } \\
\text { winter fallow, hot and dry) }\end{array}$ & $\begin{array}{l}\text { Egypt, Iran, Italy, Spain, California (USA), } \\
\text { Peru, south-eastern Australia }\end{array}$ & 1 \\
\hline 5 & Rainfed lowland & Tropics & $\begin{array}{l}\text { Cambodia, North-East Thailand, } \\
\text { eastern India, Indonesia, Myanmar, Nige- } \\
\text { ria }\end{array}$ & 31 \\
\hline 6 & Rainfed upland & Tropics & $\begin{array}{l}\text { South Asia, South-East Asia, Brazilian } \\
\text { Cerrado, western Africa }\end{array}$ & 9 \\
\hline 7 & Deep water & Tropics & $\begin{array}{l}\text { River deltas of South Asia and South-East } \\
\text { Asia, Mali }\end{array}$ & 3 \\
\hline
\end{tabular}

Percentage of world area; percentages apply to global rice area around 2008-10 (160 Mha). *Mha=Million hectare.

Table 4. Major Rice Production Environments (RPEs) in Nepal.

\begin{tabular}{lllll}
\hline RPEs & Agro-ecology (Climate) & Hydro-morphology & Topography & Cropping system \\
\hline 1. Irrigated & Terai and Inner Terai Tropical & Irrigated & Lowland & Single crop \\
& Terai and Inner Terai Tropical & Irrigated & Lowland & Double crop \\
& Terai and Inner Terai Tropical & Irrigated & Lowland & Triple crop \\
& Mid hill sub-tropical & Irrigated & Terraces Khet & Double crop \\
& Mid hill sub-tropical & Irrigated & Terraces Khet & Single crop \\
& High hill warm temperate & Irrigated & Terraces Khet & Single crop \\
2. Rainfed & Terai and Inner Terai Tropical & Rainfed & Lowland & Single crop \\
& Terai and Inner Terai Tropical & Rainfed & Upland Pakho & Single crop \\
& Mid hill sub-tropical & Rainfed & Upland Pakho & Single crop \\
\hline
\end{tabular}


Rice based cropping systems in Nepal under various RPEs Several crop combinations in rice based areas are in practice which is determined by agro-ecology and climate, hydro-morphology, topography, market and domestic needs. Some of the popular rice based cropping systems are summarized below.

\section{Rice-maize mixed cropping}

System of mixing direct seeds upland rice with maize under rainfed condition is a tradition practice in the far western terai and river basins areas. According to farmers the mixing practice ensures higher income, maintain better soil quality and reduce risks. In general rice and maize seeds are mixed in the ration of 5 to 10:1 depending on farmers' interest and needs.

\section{Rice-legumes intercropping systems}

Farmers in Nepal grow rice intercropped with soybean (Glycine max L.), blackgram (Phaseolous mungo L.), greengram (P. radialus L.), pigeonpea (Cajanus cajan L.) etc utilizing the bunds in the rice terraces. This practice is common in both the irrigated and rainfed systems.

\section{No till Relay cropping system}

The seed of succeeding winter crops like lentil, gram, pea, lathyrus etc. is broadcasted in muddy or marshy conditions of maturing rainy season rice fields during the month of November. The rice crop is harvested within few days, leaving the seeds to germinate and grow utilizing the residual soil moisture.

\section{Sequential cropping}

Several rice based sequential cropping systems prevails in Nepal depending upon the agro-climatic, hydromorphic and topographic conditions. Major sequential cropping systems in the rice growing areas include Ricewheat-fallow (Irrigated); Rice-wheat-rice (Irrigated); Rice-maize-rice or fallow (irrigated); Rice-wheat-maize (Irrigated); Rice-fallow-fallow (rainfed); Rice-barley or wheat (irrigated) etc.

\section{Integrated rice farming}

Rice-Fish-Poultry and Rice-Fish-Duckery are also practiced in the terai regions of Nepal. This system ensures better yield for rice and poultry/duck. Birds and fish add manures in the soil and eat insect pests and help to circulate oxygen in the rice field. Fish grown in the paddy fields, is ideal use of land and easy source of cheap animal proteins. Thus fish culture can contribute to the socio-economic and nutrition welfare of rural populations.

Table 5. Major sequential cropping system in Nepal.

\section{i. Terai (<1000 masl)}

\begin{tabular}{|c|c|}
\hline Irrigated area & Rainfed area \\
\hline Rice-wheat-rice & Rice-fallow-fallow \\
\hline Rice-wheat-fallow & Rice-wheat-fallow \\
\hline Rice-wheat-Dhaicha & Rice-lentil-fallow \\
\hline Rice-wheat-mung & Rice-rapeseed-fallow \\
\hline Rice-maize-rice & Rice-fallow-tobacco \\
\hline Rice/lentil-rice & Jute-rapeseed-fallow \\
\hline Rice-chickpea, linseed & Jute-wheat-fallow \\
\hline Rice-wheat-maize & Maize-chickpea, lentil \\
\hline Rice-potato-Dhaicha & Rice/lentil \\
\hline Rice-peasonpea (in bund)- wheat & Maize-chickpea+rapeseed \\
\hline Rice-potato-maize & \\
\hline \multicolumn{2}{|l|}{ ii. Mid-hill (1000-2000 masl) } \\
\hline Irrigated area & Rainfed area \\
\hline Rice-wheat-fallow & Maize/millet-wheat \\
\hline Rice-wheat-rice & Maize/millet-fallow \\
\hline Rice-wheat-maize & Maize + soybean-rapeseed-fallow \\
\hline Rice-black gram (in bund)-wheat & Maize-wheat \\
\hline Rice-barley & Maize-oat \\
\hline Rice-maize & Maize + upland rice \\
\hline Rice-rapeseed-maize & Maize + upland rice- wheat \\
\hline Rice-rapeseed-rice & \\
\hline Rice-potato-maize & \\
\hline \multicolumn{2}{|l|}{ iii. High hill } \\
\hline Irrigated area & Rainfed area \\
\hline Rice-barley & Maize -fallow \\
\hline Rice- necked barley (uwa) & Maize -wheat \\
\hline Rice-wheat & Wheat- finger millet (2 years cropping pattern) \\
\hline Buckwheat- necked barley (uwa) & Maize- necked barley (uwa)-finger millet ( 2 years cropping pattern) \\
\hline $\begin{array}{l}\text { Potato + necked barley (uwa) - fallow ( } 2 \text { years cropping } \\
\text { pattern) }\end{array}$ & Maize-wheat-finger millet 2 years cropping pattern) \\
\hline $\begin{array}{l}\text { Rice-fallow-finger millet-barley-wheat ( } 2 \text { years cropping } \\
\text { pattern) }\end{array}$ & $\begin{array}{l}\text { Potato-fallow, potato-buckwheat, maize-rapeseed, uwa-fallow, maize- } \\
\text { buckwheat }\end{array}$ \\
\hline
\end{tabular}


Conclusion

Rice is a major food crop for Nepal and for the world. Its production should be encouraged so that it could lead the country to achieve the sustainable food security. Rice is cultivated in diverse agro-ecosystems and its production is greatly affected by its growing environments. Identification and classification of precise rice growing environments helps national rice breeding program for accessing appropriate rice germplasm from international sources; develop environment specific rice varieties and agronomic practices.

\section{ACKNOWLEDGEMENTS}

This study did not receive funding from external sources. The authors are thankful to the National Rice Research Program (NRRP), Hardinath, Dhanusha and Communication, Publication and Documentation Division (CPDD), Khumaltar, Lalitpur for providing information for this article.

\section{Conflict of interest}

The authors declare that there are no conflicts of interest.

Open Access: This is an open access article distributed under the terms of the Creative Commons Attribution 4.0 License, which permits unrestricted use, distribution, and reproduction in any medium, provided the original author(s) if the sources are credited.

\section{REFERENCES}

Agrama, H.A., Yan, W., Jia, M., Fjellstrom, R. and McClung, A.M. (2010). Genetic structure associated with diversity and geographic distribution in the USDA rice world collection. Natural Science, 2(04): 247.

Alexandratos, N. and Jelle, B. (2012). World agriculture towards 2030/2050: the 2012 revision. FAO Agricultural Development Economics Division. Food and Agriculture Organization of the United Nations. www.fao.org/economic/esa

Alias, B. A., Shoichi, Ito and Kelali, A. (2005). Estimate of Rice Consumption in Asian Countries and the World Towards 2050. Tottori University

CDD. (2015). Rice varietal mapping in Nepal: Implication for development and adoption. Crop Development Directorate, DoA, Hariharbhawan, Lalitpur.

CGIAR. (2016). The global staple. http://ricepedia.org/rice-asfood/the-global-staple-rice-consumers
Dawe, D., Pandey, S. and Nelson, A. (2010). Emerging trends and spatial patterns of rice production. In: Pandey, S., Byerlee, D., Dawe, D., Dobermann, A., Mohanty, S., Rozelle, S. and Hardy, B. (Eds). Rice in the global economy: strategic research and policy issues for food security. Los Baños (Philippines): International Rice Research Institute. pp. 1535.

FAO. (2017). The future of food and agriculture - Trends and challenges. Rome. http://www.fao.org/3/a-i6583e.pdf

Fischer, R. A., Byerlee, D. and Edmeades, G.O. (2014). Crop yields and global food security: will yield increase continue to feed the world?. Canberra: Australian Centre for International Agricultural Research. http://aciar.gov.au/publication/mn158

GRISP. (2013). Rice Almanac, $4^{\text {th }}$ Edition. Global Rice Science Partnership, International rice Research Institute., Los Banos, Philippines. pp. 283

Kharel, L., Ghimire, S.K., Shrestha, J., Kunwar, C.B. and Sharma, S. (2018). Evaluation of rice genotypes for its response to added fertility levels and induced drought tolerance during reproductive phase. Journal of AgriSearch, 5(1): 13-18.

Khus, G.S. (1984). Terminology for Rice Growing environments. International rice Research Institute. Los Banos, Philippines

Mallick, R.N. (1982). Rice in Nepal. Kathmandu. Kala Prakasan.

MOAD. (2017). Statistical Information on Nepalese Agriculture, 2016/17. Ministry of Agricultural Development, Singh Durbar, Kathmandu.

Peng, S., Khush, G.S., Virk, P., Tang, Q. and Zou, Y. (2008). Progress in ideotype breeding to increase rice yield potential. Field Crops Research, 108(1): 32-38.

Serraj, R., McNally, K.L., Slamet-Loedin, I., Kohli, A., Haefele, S.M., Atlin, G. and Kumar, A. (2011). Drought resistance improvement in rice: an integrated genetic and resource management strategy. Plant Production Science, 14(1): 1-14.

Singh, R.B., Woodhead, T. and Papademetriou, M.K. (2002). Strategies to sustain and enhance Asia-Pacific rice production. Proc of the 20th session of the international rice commission, Bangkok, Thailand.

Swaminathan, M.S. (1984). Terminology for Rice Growing environments. International rice Research Institute. Los Banos, Philippines

USDA/ERS. (2016). Rice Outlook- 2016 by Nathan Childs. http://www.ers.usda.gov/data-products/internationalbaseline-data.aspx\#56954

Yuan, L.P. (2017). Progress in super-hybrid rice breeding. The Crop Journal, 5(2): 100-102. 